\title{
Dual Transformation in Print Media Case Study of Adiluhung Magazine
}

\author{
Faustina Easter Koesvardani ${ }^{1}$, Johny Natu Prihanto ${ }^{2}$, Kristianus Ade Sudiyono ${ }^{3}$ \\ \{faustina.easter@student.umn.ac.id ${ }^{1}$,johny.natu@umn.ac.id ${ }^{2}$, \\ adesudiyono@gmail.com ${ }^{3}$ \} \\ Master in Management Technology, Universitas Multimedia Nusantara ${ }^{1}$, Faculty of Management \\ Technology, Universitas Multimedia Nusantara ${ }^{2}$, Faculty of Management Technology, Universitas \\ Multimedia Nusantara ${ }^{3}$

\begin{abstract}
This research helps Adiluhung Magazine to do dual transformation strategy so they can compete in this industry and reached the new segmentation. The problem of uneven distribution of the magazines, resulting in a decrease in the number of advertisers, which influences the revenue streams. Another problem is they have unreached segmentation of customers, which is generation $\mathrm{Y}$ and $\mathrm{Z}$. There is no other research that discusses dual transformation based on the Digital Maturity Model (DMM) applied to the project. This research using a questionnaire based on DMM's to get feedback from customers and employees to measure the company's current stage. Then using focus group discussions and interviews with top management and customer for validation, to know the current stage and determine the future stage, that can find the gap and can be filled with initiative to achieve the future state.
\end{abstract}

Keywords: Dual transformation, Digital Transformation, Digital maturity model, Digital marketing, Generation Y and Z.

\section{Introduction}

This research taking a firm of Digital Transformation Project, based on a case study of Adiluhung Magazine. The print media industry is experiencing a decline due to the preference of readers who have switched to digital media. Research reveals that as many as $64 \%$ of the Indonesian population has become internet users [1]. It also affects the Adiluhung magazine which has a theme about Indonesian culture, such as puppets (Wayang), batik, kris, and traditional culinary. This magazine experienced a 38\% decrease in sales that occurred in 2018 and a $25 \%$ decrease in advertising. This is mutually influential because with the decline in magazine sales, it also has an impact on the decrease in advertisements published in magazines [2]. The reduction in sales also occurred due to the uneven distribution of these magazines. Many customers complain that the magazine is hard to find, and they also don't know that Adiluhung magazine has an e-book version. (Internal Source, 2020) Because of that, the Adiluhung magazine wants to maximize the use of their social media in its marketing. The use of social media platforms can make access easier for customers, connect advertisers, and share information [3]. Another problem is that Adiluhung magazines have unreached segmentation, which is gen $\mathrm{Y}$ and $\mathrm{Z}$. They only can reach the $\mathrm{X}$ generation. In this paper, the classifications of these generations are Gen X whose born in 1960-1980, Gen Y or millennial whose born in 19801995, and Gen Z whose born in 1995-2010 [4]. 82\% of their customer is X generation. So it is 
felt necessary to create new media that can target $\mathrm{Y}$ and $\mathrm{Z}$ generation and also still maintaining its print media to retain existing customers. In reaching gen $\mathrm{Y}$ and $\mathrm{Z}$, changing the business model in print media is important so that the content that is owned can be delivered with other media that is more popular with the appropriate segmentation [5]. The new media chosen to deliver content is video, because in the 2020 digital survey: Indonesia, $99 \%$ of people use the internet to watch videos [6]. New media itself has several characteristics, such as digital or interactive media; hypertextual or can obtain information quickly; can be enjoyed visually as well as audio-visual; and simulations, so it is possible to simulate to see if it happens in the real world. [7]. To maintain the old segmentation, improving marketing strategy, and creating new media to target new segmentations, a dual transformation strategy will be applied. Dual transformation is a method to reposition its business so that it can continue to compete in this industry, and provide new media that is suitable for the intended segmentation [8]. This strategy is carried out with the Digital Maturity Model (DMM) approach.

\section{Literature Review}

\subsection{Dual Transformation}

Dual transformation is a method to reposition existing businesses to be able to compete in today's industry and create businesses for new growth. To repositioning today's business, we need to transform today's core business to face today's industry, that's called transformation A and Transformation B is creating the new business, to create new growth. Thus creating a transformation $\mathrm{C}$ which is the link between transformations $\mathrm{A}$ and $\mathrm{B}$ [9].

\subsection{Digital Maturity Model (DMM)}

Digital Maturity Model or DMM is a framework to help organizations to do digital transformation. This model also measures the current conditions and helps determine the future state of the company. In the framework there are 5 dimensions, namely Customer, Operation, Strategy, Technology, and Culture. In each dimension, there are sub-dimensions. There is also 5 stage to measure maturity of the dimension, which is 1- Initiating, 2-Emerging, 3-performing, 4-Advancing and 5-Leading [10].

\subsection{Generation $\mathrm{X}, \mathrm{Y}, \mathrm{Z}$}

Generations are divided into 4 classifications. First, baby boomers who were born in 19461960, Gen X whose born in 1960-1980, Gen Y or millennial whose born in 1980-1995, and Gen $\mathrm{Z}$ whose born in 1995-2010. They also have different characteristics. The $\mathrm{Y}$ and Z generations are more digital savvy and can do such a various thing in one time or can multitasking [11].

\subsection{Digital Marketing}

Modern marketing or now called digital marketing is marketing that is supported by the Internet and media technology. It called digital marketing because it is through the medium of the internet, electronic marketing, and web marketing [12]. Social media provides opportunities to 
build, maintain and strengthen social and professional relationships between people. It also can help in executing relationship marketing strategies to build long term customer relationships[13].

\subsection{Case Study}

The company that used in this case study is a company that produces print media with theme of Indonesian culture called "Adiluhung Magazine". The magazine was founded in 2013 and have reviews various kinds of Indonesian culture, especially about Wayang (Indonesian Puppet), Kris, Batik and Traditional Culinary of Indonesia. The sales of the magazine were through agents, bookstores, and entrusted to restaurants that served Indonesian specialties. In 2014, Adiluhung Magazine began to become a sponsor for cultural events and began collaborating with cultural agencies. In 2017, Adiluhung Magazine started selling its products through individual partners, that sell the magazine in their shop in one of the well-known e-commerce sites in Indonesia. Also in that year, Adiluhung Magazine created social media which is expected to communicate and advertise its products to customers. But until now, things have not worked out the way they should. In 2019, there was a decline in sales from print magazines (Internal Source, 2019), so that Adiluhung magazine took steps to create a website and also sell its digital version via Google Play Book, but sales results are not that good. After that happened, the Adiluhung magazine tried to conduct a survey that was distributed to customers and noncustomers who were millennials, and it was found that $30 \%$ of the respondents complained that the marketing was uneven in some areas, $24 \%$ suggested the existence of digital media compared to print media, and the rest contains criticism and suggestions about the content. From this it can be concluded that the marketing of both print and digital magazines is lacking.

The Owner of Adiluhung magazines said that they have unreached segmentation, which is gen $\mathrm{Y}$ and $\mathrm{Z} .82 \%$ of their customer is $\mathrm{X}$ generation. So they felt necessary to create new media that can target $\mathrm{Y}$ and $\mathrm{Z}$ generation and also still maintaining its print media to retain existing customers. To maintain the old segmentation, improving marketing strategy, and creating new media to target new segmentations, a dual transformation strategy will be applied. The purpose of this research is to produce a roadmap to help companies to do dual transformation in order to know the strategies that must be done to achieve the target.

Research begins with making a questionnaire based on DMM and then distributed to employees and customers of Adiluhung magazine. Then the results of the questionnaire were validated by interviewing customers who were classified as gen $\mathrm{Y}$ and $\mathrm{Z}$ Responden $\mathrm{A}$ which is $\mathrm{Y}$ generation is 25 years old, and responden $\mathrm{B}$ which is $\mathrm{Z}$ generation is 15 years old. Responden A said that he would be buy Adiluhung magazine if it's easy to get, for examples, they can buy it online. Then author ask if he knows about the e-books that Adiluhung had, and he said no. the author also ask about the social media of Adiluhung, if they can had enough information about the content or how to get the magazine, and he says no, he also barely found Adiluhung offline, he said that he only can found the magazine because his friend subscribed to the magazine. He also hope that Adiluhung magazine can do marketing and had online media, so that people are more aware and it's more easily to get the magazine or knows the content. Respondent B said that he also had problem to get the print magazine, so he will be happy if Adiluhung had their online media. He also doesn't know if Adiluhung had their e-books, even though he is the followers of Adiluhung magazine social media. He said that it would be easier if Adiluhung had video or podcast format. He also recommend Adiluhung magazine to maintain its social media and upload the fun fact about Indonesian culture, so the $\mathrm{Z}$ generation is more interested. 
From that data, the author validate that by conducting FGD with the owner and artistic. The results show that according to all dimension from DMM, the Adiluhung magazine is still in the 2-Emerging level, and the owner wants the company to be able to go up to the 3Performing level in 1 year. To achieve that and to fill the gap, the author created 2 roadmaps. The first roadmap, which is the transformation A, is to solve the problem of uneven sales and customer lack of knowledge of the products of the magazine, and the second, which is the transformation B is to solve the problem of target segmentation that has not been reached. Each roadmap had 4 stages, so one step is predicted to be done in 3 months.

\section{Research Result and Discussion}

From the results of calculating the mean from the questionnaire, it was found that the Culture dimension had a score of 2.20, Technology with a score of 2.38, Customer with a score of 2.47, Operations with a score of 2.56, and Strategy with a score of 2.73. So it can be concluded that the current state of this company is level 2-Emerging. From interviews with respondent A and $\mathrm{B}$ and FGD with the owner and head of artistic, found that the result was not far from these calculations. They said that Adiluhung needs more human resources that knowing about marketing in digital. The future state is set at the 3-performing level based on the owner's discussion with the author. These data can be described as shown in Figure 1.

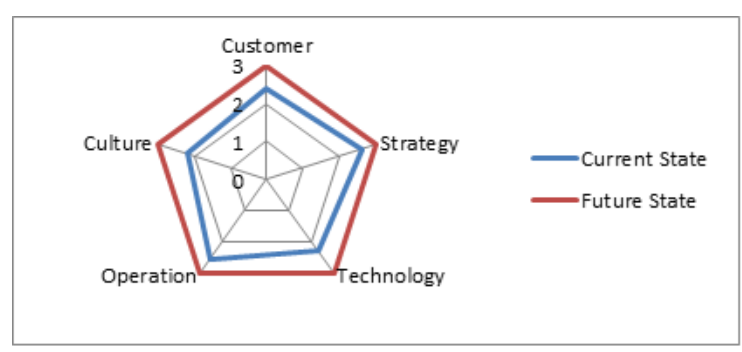

Fig.1. Radar Chart of Current and Future State of Adiluhung Magazine

From this gap, a roadmap for transformation A which is the transformation of print media was created. This roadmap had 4 stages that contain activities that must be carried out by the company in reaching the level that already determined. The first step in this stage is where the strategy is planned, in the customer dimension, the company has to prepare to apply a new design and prepare to maximize the use of their social media. In the strategy and technology dimension, companies have to prepare to maintain their website and social media to gather customer insight and marketing their product. In the operation and culture dimension, the company planning to train the employee. Stage 2 is the preparation stage, for example in this case is hire admin and doing training. The third stage is for doing trial and error to apply new strategies and using new applications. Stage 4 is where the strategy has been implemented. The second roadmap is made for the creation of video media which is transformation $\mathrm{B}$. In this second roadmaps, it also has 4 stages. In the first stage of preparing in each dimension, the second stage is for hiring the source that needed, research to do marketing for video, 
procurement of goods, and also applying the apps that needed. In the third stage, the company has to maintain the website and social media, so they adaptable for video and can be used for marketing the video format, creating the video who will reach generation $\mathrm{Y}$ and $\mathrm{Z}$. trial error using the apps for video producing. The last stage is all dimensions are fully applied and the video can be produced and promote in all defined media.

\section{Conclusion}

This research was conducted to determine the gaps that cause problems for the magazine with the Indonesian culture theme that will perform a dual transformation, so the gap can be filled with a roadmap so that companies can carry out digital transformations to be able to remain competitive in today's industry and can reach their unreached segmentation with new media. The gap is founded in all 5 dimensions. This research produces 2 roadmaps that can help the company to exploit existing resources to fill the gap, and exploring new resources to make new media for new segmentation in using their print media format and video format. In print media format they have to maximize their design and social media in order to market their products, they also had to recruit the admins for their social media, because there is no one who really capable to maintain it. They also had to maintain their website to promote and share the content there. To support its digitalization, the companies also have to train their employee to use the application to be used. In video format, they have to maximize the website, as a place to market their digital products and their print media. They also have to recruit the new team to make new videos and have to provide the equipment for video making.

\section{Implication/Limitation and Suggestion for Further Research}

The two roadmaps that are created will help the company to achieve its goals in carrying out dual transformations, so they can reach new segmentations which are generations $\mathrm{Y}$ and $\mathrm{Z}$, and still maintaining the old segmentation which is generation $\mathrm{X}$. In transformation A which is the print media transformation, the roadmap can help the company to apply strategies to fulfill the gap that occurs in each sub-dimensions which are made magazine designs more attractive, and marketing through websites and social media. With that instrument, the customer insights can be tracked and can easily reach the targeted segmentation. Company also have to train their employees in using applications related to digitization projects, so work can run smoothly and data can be neatly organized.This transformation expected to gain and replace the old marketing strategy. In transformation $\mathrm{B}$, which is a video creation project for a new segmentation, the roadmap helps companies guide the planning of making videos to deliver content that is in line with the print magazine. But this study has its limitations because not all dimensions in the DMM are used. If possible, future research can use all dimensions, so can produce new findings.

\section{References}

[1] Kemp, S.: Digital 2020: Indonesia.” DataReportal - Global Digital Insights, datareportal.com/reports/digital-2020-

indonesia\#: :text=There\%20were\%20175.4\%20million\%20internet. p. 24 (2020) 
[2] Permana,D.J: Analisis Peluang Bisnis Media Cetak Melalui Pendekatan Bisnis Model Canvas Untuk Menentukan Strategi Bisnis Baru. p. 309-319 (2013)

[3] Utomo, P.: RENCANA PENGEMBANGAN MEDIA PROMOSI DIGITAL DESA KERANGGAN. (2019)

[4] Putra, Y S.: THEORITICAL REVIEW : TEORI PERBEDAAN GENERASI. (2016)

[5] Margrit, A: INDUSTRI MEDIA CETAK : Perubahan Model Bisnis Penting. (2017)

[6] Kemp, S.: Digital 2020: Indonesia.” DataReportal - Global Digital Insights, datareportal.com/reports/digital-2020-

indonesia\#: :text=There\%20were\%20175.4\%20million\%20internet. p. 31 (2020)

[7] Rohimah, A.: Era Digitalisasi Media Pemasaran Online Dalam Gugurnya Pasar Ritel Konvensional p. 91 (2019)

[8]Anthony, D S.: Dual Transformation: How to Reposition Today's Business While Creating the Future. p. 27 (2017)

[9] Anthony, D S.: Dual Transformation: How to Reposition Today's Business While Creating the Future. p. 27-29,47-50 (2017)

[10] Deloitte, and TMForum.: Digital Maturity Model Achieving Digital Maturity to Drive Growth.(2018)

[11] Putra, Y S.: THEORITICAL REVIEW : TEORI PERBEDAAN GENERASI. (2016)

[12] Chaffey, Dave, and Fiona Ellis-Chadwick.:Digital Marketing: Strategy, implementation and Practice. P. 38 (2016)

[13] Jacobson,J.: Social Media Marketing: Who Is Watching the Watchers? (2019) 